Nat. Hazards Earth Syst. Sci., 18, 2951-2968, 2018

https://doi.org/10.5194/nhess-18-2951-2018

(C) Author(s) 2018. This work is distributed under

the Creative Commons Attribution 4.0 License.

\title{
How the impacts of burst water mains are influenced by soil sand content
}

\author{
Timothy S. Farewell ${ }^{1}$, Simon Jude ${ }^{1}$, and Oliver Pritchard ${ }^{2}$ \\ ${ }^{1}$ School of Water, Energy and Environment, Cranfield University, Bedford, MK43 0AL, UK \\ ${ }^{2}$ Arup, Blythe Gate Blythe Valley Park, Solihull, B90 8AE, UK
}

Correspondence: Timothy S. Farewell (t.s.farewell@cranfield.ac.uk)

Received: 5 December 2017 - Discussion started: 12 December 2017

Revised: 17 August 2018 - Accepted: 21 August 2018 - Published: 9 November 2018

\begin{abstract}
Society relies on infrastructure, but as infrastructure systems are often collocated and interdependent, they are vulnerable to cascading failures. This study investigated cross-infrastructure and societal impacts of burst water mains, with the hypothesis that multi-infrastructure failures triggered by burst water mains are more common in sandy soils. When water mains in sandy soils burst, pressurised water can create subsurface voids and abrasive slurries, contributing to further infrastructure failures. Three spatial data investigations, at nested scales, were used to assess the influence that soil sand content has on the frequency and damage caused by burst water mains (1) to roads in the county of Lincolnshire, (2) to other proximal water mains in East Anglia and (3) to other proximal infrastructure and wider society across England and Wales. These investigations used infrastructure network and failure data, media reports and soil maps, and were supported by workshop discussions and structured interviews with infrastructure industry experts. The workshop, interviews and media reports produced a greater depth of information on the infrastructure and societal impacts of cascading failures than the analysis of infrastructure data. Cross-infrastructure impacts were most common on roads, built structures and gas pipes, and they occurred at a higher rate in soils with very high sand contents.
\end{abstract}

\section{Introduction}

The socio-economic and physical wellbeing of society is increasingly dependent on infrastructure services (Lloyds Register Foundation, 2015; Guikema, 2015; Defra, 2013). Infras- tructure assets (e.g. pipes, cables, roads, substations, pumping stations and buildings) are commonly co-located, so a failure of one asset (e.g. a burst water main) may lead to failures in proximal networks (e.g. damage to a road, and/or flooding of gas networks). Complex infrastructure failures can be cascading, be escalating or have a common cause (Rinaldi et al. 2001). They can occur at a range of spatiotemporal scales and affect both physical and socio-political infrastructure.

Multi-infrastructure failures often result from a single failure in the crowded and heterogeneous array of co-located, aged and modern, interconnected and semi-automated infrastructure systems (Pritchard et al. 2014a). These systems operate with physical, geographic, functional, cyber, policy and informational dependencies and interdependencies (Rinaldi et al., 2001; Zimmerman, 2004; Dudenhoeffer et al., 2006). These close relationships can make infrastructure vulnerable to complex failures. Potential for the initial infrastructure failure is influenced by both inherent infrastructure factors (e.g. for water mains, these may include age, material, diameter, joint technology, workmanship, co-location, pressure management, investment) and environmental factors (e.g. soil, vegetation, extreme or rapidly changing weather). Rapid or extreme environmental changes often expose the vulnerabilities of aging and deteriorating infrastructure networks.

An example of how burst water mains can impact other infrastructure networks occurred in Matlock, Derbyshire, UK (Appendix A; BBC, 2013a). Here, flooding from a burst main closed two roads, disrupting transport across the city. Escaping water formed a void under the road surface, into which a water company van fell, fracturing a gas main. The gas leak forced the evacuation of 25 homes, water and sedi- 
ment flooded the gas network and the County Hall suffered flood damage (including to official records) and was closed for days. This single burst damaged roads, gas networks and buildings. It impacted government functions and required police and fire service resources. Whilst direct costs of this complex failure totalled many tens of thousands of pounds, indirect costs to society were much higher.

Risks to infrastructure assets represent a key strategic risk for the water sector, and the heterogeneity of infrastructure assets, networks and the soil environment, in which they are buried, produces complexity for infrastructure operators and regulators tasked with providing robust and resilient levels of service (Rinaldi et al., 2001; Rogers et al., 2012; Chalker et al., 2018). With the limited awareness amongst infrastructure asset managers of system-of-systems thinking, which is rarely employed in asset risk assessments, and the limited communication between operators, governments and regulators, understanding of infrastructure interdependencies is often lacking (Young and Hall, 2015; Defra, 2011; Jude et al., 2017; Street et al., 2017; Committee on Climate Change, 2017). Indeed, the second UK Climate Change Risk Assessment (CCRA) identified cascading infrastructure failures as the highest risk facing UK infrastructure (Dawson et al., 2016). Furthermore, the CCRA recommends greater consideration of subsidence risks to infrastructure and improved risk information sharing between infrastructure operators (Dawson et al., 2016).

One significant challenge associated with developing an understanding of such infrastructure risks is that natural hazards to the built environment have different frequencies, impacts and spatio-temporal scales. In particular, whilst a considerable body of literature exists surrounding acute environmental hazards such as flooding (e.g. Bowering et al., 2014), less research explores more complex, and often chronic, forms of soil-related natural hazards and related infrastructure failures (Defra, 2011). Such hazards pose substantial risks to infrastructure systems that may be currently underestimated by stakeholders. Because risk perception is often linked to past experience (Taylor et al., 2014), the impact of low-frequency events with moderate-high impacts may be underestimated by infrastructure operators, as they may not be high on organisations' risk registers.

Soils support infrastructure, yet some soils are prone to forms of ground movement including clay shrink-swell, sand washout and peat shrinkage (Pritchard et al., 2014a; $2015 \mathrm{a}, \mathrm{b})$. While the process of clay-related soil movement is relatively well understood, little is currently known about the likelihood of complex infrastructure failures resulting from water pipe bursts in soils with different sand contents. Of particular concern are sandy soils with greater than $70 \%$ sand-sized particles $(0.06-2 \mathrm{~mm})$. Whilst sandy soils cover less than $20 \%$ of England and Wales, they are susceptible to water-assisted erosional processes and are not uncommon in some urban settings (Brink et al., 1982; Cranfield University, 2016). Thus, water escaping from buried pipes can form voids, removing the structural support normally offered by soil to infrastructure (bridging). In addition, sand and pressurised water can form abrasive slurries, which are highly damaging to proximal plastic pipes (Majid et al., 2010).

This paper presents an interdisciplinary scoping study exploring the influence of sandy soils on the impacts of burst water mains on physical infrastructure (electricity, natural gas, water, wastewater, transport and telecoms), public service infrastructure, (government, emergency services, healthcare and education) and wider socio-economic functions. The hypothesis is that sandier soils are more likely to give rise to multi-infrastructure failures due to their non-cohesive structure (leading to void formation) and composition of large, abrasive particles that, under the release of high pressure water, can damage proximal infrastructure. A mixedmethods approach is used to help understand the wideranging impacts of these events. Four methods and multiple sources of evidence are used. Discussion focuses on the impacts of burst water mains on infrastructure systems and wider society.

Three spatial data investigations, at nested scales, were used to assess the influence that soil sand content has on the frequency and level of damage caused by burst water mains: (1) to overlying roads in the county of Lincolnshire (2) to other proximal water mains in the region of East Anglia and (3) to other proximal infrastructure and wider society across England and Wales (Figs. 1 and 2). Lincolnshire is found within East Anglia, which is in turn found within England (Fig. 2). In addition, both a series of one-to-one interviews and a joint workshop with infrastructure practitioners were used to elicit expert industry knowledge of the impact of burst mains on infrastructure systems and wider society. The choice of the different study areas was guided by the availability of data of sufficient quality and quantity.

\section{Data}

This study required data on (1) the distribution of infrastructure networks, (2) the location of infrastructure failures and (3) the related soil conditions. Nine datasets were collected and used in exploratory data analysis, but only six were sufficiently complete, consistent and coherent with the failure mechanisms under investigation to warrant their inclusion in the full study. Industry-provided datasets that were not used included electrical faults data (which were sparse and lacked accurate spatial location) and the sewer network data and sewer failures data (which lacked accurate dates of failure, and in addition, most failures reported were blockages, which lack a strong mechanistic link to burst water mains). The flow of data through the methods is described in Fig. 1 and the locations of the smaller study areas are shown in Fig. 2. 


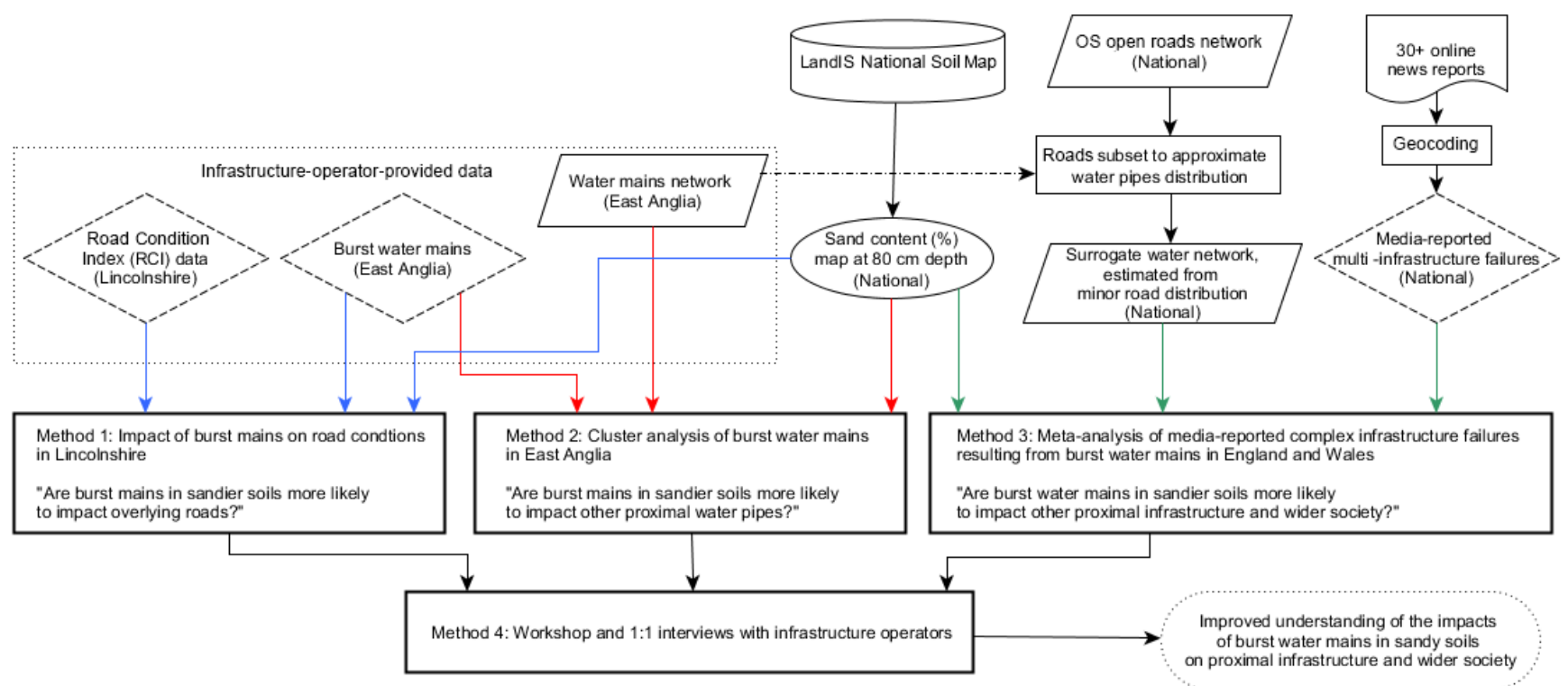

Figure 1. The flow of data and information between the methods.

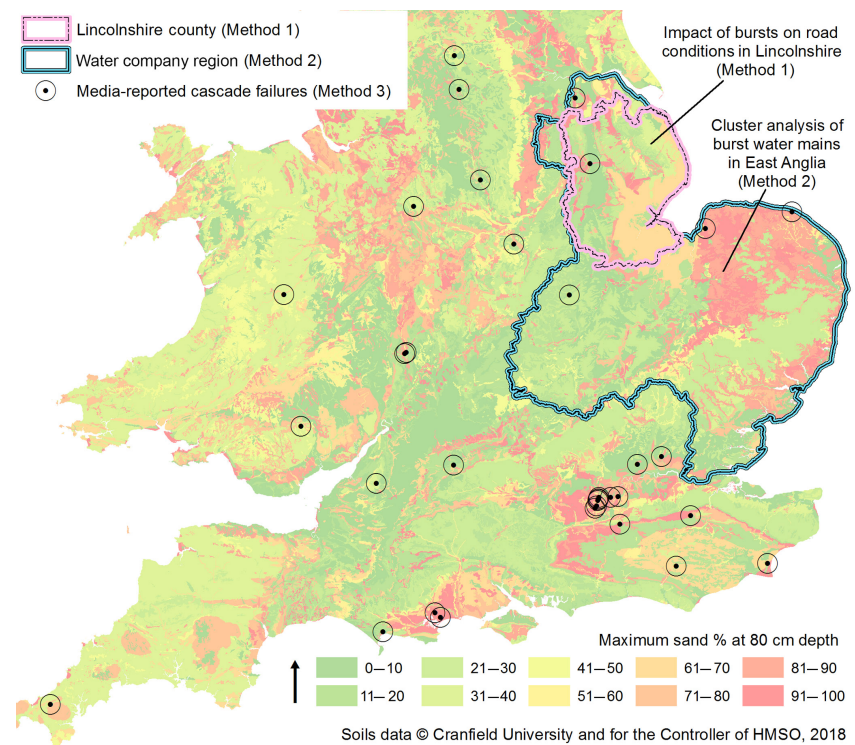

Figure 2. Map of maximum sand content at $80 \mathrm{~cm}$ depth for England and Wales, with the study areas for the different methods, and media-reported cascade failures, which are described in detail in Appendix A.

\subsection{Infrastructure network data}

In order to calculate rates of infrastructure failure, it was necessary to know the location and lengths of infrastructure networks. Road network data were available for England and Wales from the Ordnance Survey OpenData (OS, 2016). The water mains network (length approximately $43000 \mathrm{~km}$ ) was available for East Anglia. Because the entire water network for England and Wales was not available, it was necessary to approximate the location of the national water network. To do so, a comparison was made of the road network data and water mains data in East Anglia. The length of water mains in each soil map unit across the UK (Fig. 2) was then estimated using the "A", "B" and "Unclassified" roads from the OS Open Roads data (OS, 2016) as a surrogate for national water mains. In East Anglia, this estimate results in a $7 \%$ underestimate of the length of pipe $(39669 \mathrm{~km}$ roads vs. $43000 \mathrm{~km}$ pipes). This error is sufficiently small for the purposes of this research, and no spatial bias in the linear infrastructure data was observed. In addition, as the water mains data contain additional small lengths of "non-mains" pipes to hydrants and washout legs, the actual underestimate of mains pipes may be less than $7 \%$.

\subsection{Infrastructure failure/condition data}

Three types of infrastructure failure/condition data were used in this study:

1. Road condition. Road Condition Index (RCI) data describing the quality of the road surface were available for the county of Lincolnshire between 2008 and 2013.

2. Burst water mains. The location and reported dates for 50901 burst water mains between 2004 and 2016 were available for East Anglia.

3. Multi-infrastructure failures/societal impacts. 33 media-reported burst water mains which impacted other infrastructure or society between 2009 and 2017 were summarised and geocoded (Fig. 2 and Appendix A). The preparation of these data is described in more detail in the Methods section. 


\subsection{Soil sand content maps}

As the majority of water pipes are found at approximately $80 \mathrm{~cm}$ depth, maps of maximum soil sand content at $80 \mathrm{~cm}$ depth were produced for England and Wales by reclassifying the $1: 250000$ scale National Soil Map and Land Information System (LandIS) data (Cranfield University, 2016). Soil texture (the composition of sand, silt and clay) varies with depth and across the national soil mapping units (which comprise numerous soil types). The maximum sand content within the soil mapping was chosen instead of the mean to highlight areas with even small areas of sandy soil, and to minimise the over-mapping of loamy soils which results when soil textures in regional soil textures are averaged.

\section{Methods}

The interactions between the four methods, their study areas and the data used are summarised in Figs. 1 and 2.

\subsection{Method 1: The impact of burst water mains on road surface quality}

The impact of burst water mains on co-located roads was investigated across the county of Lincolnshire (Fig. 1) for which both road condition and water infrastructure data were available. Annual (2008-2013) Road Condition Index (RCI) SCANNER data were provided by highway engineers at the County Council. RCI is measured on a scale from 0 (good condition) to 315 (failed road) (Wallis, 2009; UK Roads Board, 2011; Pritchard et al, 2014b, 2015b). Roads with RCI $>100$ require maintenance.

The road quality before, and after, reported burst mains was compared. Each burst was buffered by $50 \mathrm{~m}$ to identify the surveyed road segments under the "potential influence" of the burst main (0-50 m, grey circles, Fig. 3), and an area which was presumed "beyond influence" of the burst (50$100 \mathrm{~m}$, blue circles) but representative of similar soil and road materials. RCI change from before to after a burst was calculated and analysed against soil sand content at $80 \mathrm{~cm}$ depth.

Both degraded road conditions (positive RCI) or improved conditions (negative $\mathrm{RCI}$ ) could indicate an impact from a burst main. As most road surfaces are in less than perfect condition, there are a number of scenarios in which a burst may impact the road surface quality, both positively and negatively. For example, an improved road surface may result when a burst main significantly damages the road surface, leading to an extensive repair to a large part of the road, increasing the surface quality in this location. A degraded road surface may result when a burst main does not damage the road surface, but does cause subsurface cavitation. In this case, the road may be undermined (even a number of metres from the burst), which can lead to surface deformation. In addition, road cutting to access the pipe will likely lead to a decrease in surface quality. Finally, little change in road surface quality might be expected when a burst main does not damage the road surface or cause subsurface cavitation. Here the only change should come from the impact of digging and reinstating the road. The impact here is dependent on the quality of the workmanship.

Road Condition Index (RCI) data were not available for all roads, in all years, and the opposite sides of the road were typically surveyed on alternate years (Fig. 3). The road condition survey area polygons are $10 \mathrm{~m}$ in length, but the GIS (geographic information system) representation of these lengths (inaccurately) extends well beyond the road footprint (green polygons in Fig. 3). To minimise the impact of this spatial inaccuracy, a count (rather than the area) of these polygons was used, along with their RCI scores to calculate a change in condition between the survey dates before and after the burst.

\subsection{Method 2: The impact of burst water mains on other water mains}

It is generally not possible to determine the causality of a burst main from the location and date of burst. So, to gain indications if bursts in sandier soils were more likely to trigger subsequent proximal bursts, clusters of bursts were identified using expanding spatio-temporal windows (distances of 2, 5, 10, 30 and $100 \mathrm{~m}$ and times of 1, 5, 10, 100 and 365 days). These windows were chosen to identify the different failure patterns. For example, the smaller windows (e.g. 2 days, $5 \mathrm{~m}$ ) may identify multiple bursts triggered directly by the bursts, through force transmission down the pipe, sand abrasion or failures triggered by a common cause. Longer temporal windows may identify impacts stemming from secondary impacts or chronic conditions. For instance, a road surface weakened from cutting to access the pipe, or due to voids, may increase differential traffic-loading forces on pipes and so increase the risk of failure. The number of burst clusters were compared with maximum soil sand content at $80 \mathrm{~cm}$. The rate of failure of all bursts per kilometre of pipe by sand content was also calculated. A total of 50901 bursts from Anglian Water between 2004 and 2015 were used in the analysis.

The rate of failure was calculated by dividing the number of bursts in clusters by the total number of bursts in each sand decile. By their nature, larger spatio-temporal windows have higher rates of clusters. Therefore, for comparison, the rates have been normalised by dividing the rate by the sum of all the rates, for each panel in the graph (Fig. 5). The calculation used is

normalised rate $=\left(\right.$ clusters $_{\mathrm{s}} /$ bursts $\left._{\mathrm{s}}\right) /\left(\Sigma_{\mathrm{t}}\left(\right.\right.$ clusters $_{\mathrm{t}} /$ bursts $\left._{\mathrm{t}}\right)$,

where clusters $_{\mathrm{s}}$ is the number of clustered bursts within a sand decile, bursts ${ }_{s}$ the total number of bursts within a sand decile, clusters the total number of clustered bursts in this spatio-temporal window and bursts $\mathrm{s}_{\mathrm{t}}$ the total number of bursts in this spatio-temporal window (the whole dataset). 


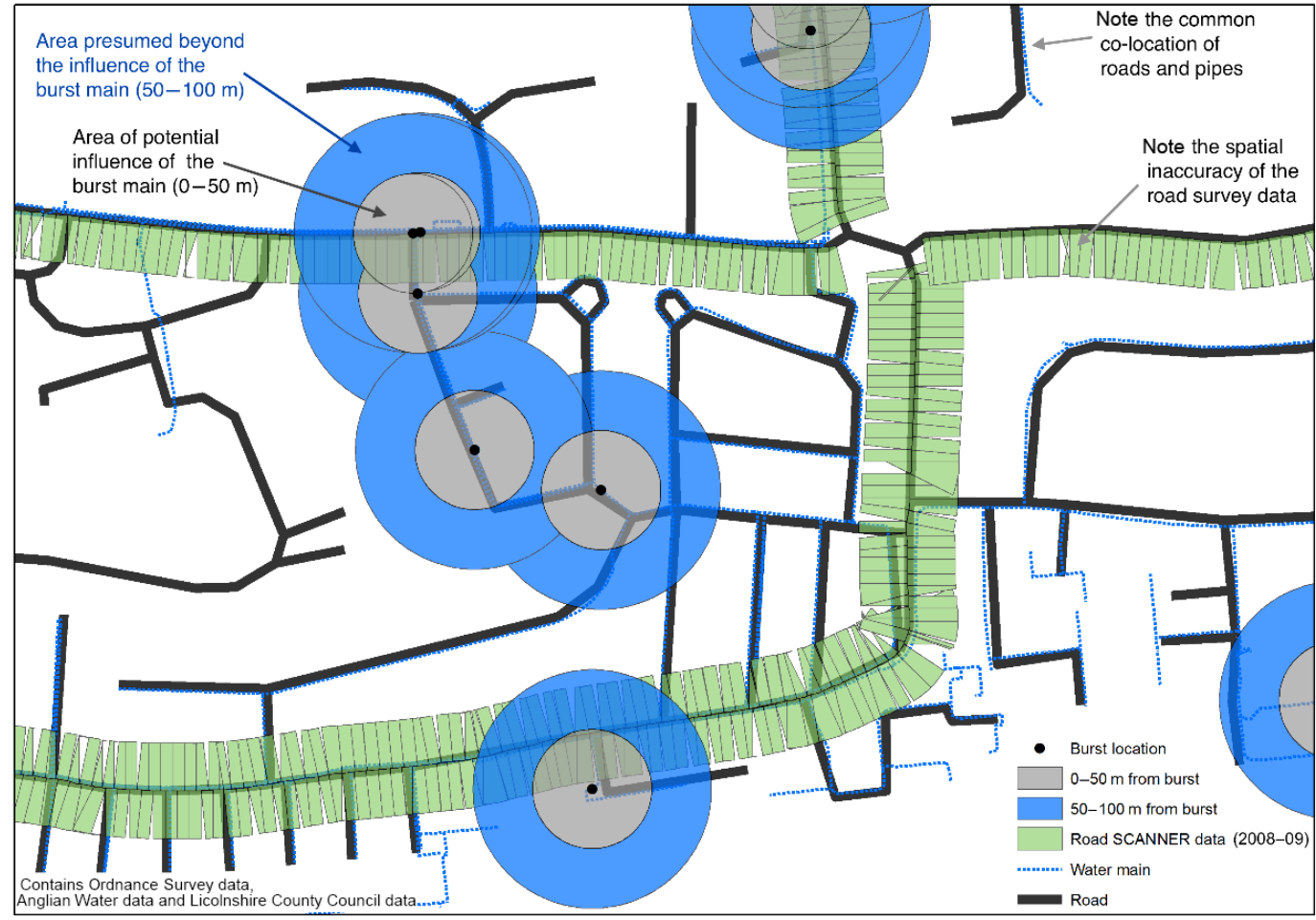

Figure 3. Example region showing road sections which potentially have been influenced by a burst, and the similar road sections which are presumed beyond the area of influence (Method 1a). Burst data are from the water company, and road data are from the local council.

\subsection{Method 3: The impact of burst water mains on other infrastructure and society}

A meta-analysis of over 30 UK local media reports between 2009 and 2017 was employed to identify the complex forms of failure arising from burst water mains. This time period was chosen for the widespread availability of UK web-based articles from this time. Google searches including keywords such as "water main", "burst", "road", "electricity", "phone, "gas" and "sewer" provided articles. The date and impacts of the burst mains were recorded (summaries are provided in Appendix A). Burst locations were estimated from the location descriptions in the articles and were geocoded with www.gridreferencefinder.com (last access: 13 September 2018). The geocoded data were imported into ArcGIS and attributed with soil sand content.

Spatial bias may (or may not) occur in the locations of the events, using this web search approach. For example, if a particular newspaper has identified cascading failures in the past, it may be more likely that they may report these issues again. Conversely, if such failures happen weekly, these events may be under-reported as they are no longer "newsworthy". Future research should consider accuracy assessments of these approaches in more detail. In this scoping study, the assumption of no spatial bias has been made. The media articles are summarised in Appendix A.

\subsection{Method 4: Cross-infrastructure workshop and 1: 1 interviews}

A single stakeholder workshop, involving representatives spanning water, electricity distribution, gas distribution and highway sectors, was used to elicit the key impacts of burst water mains on other infrastructure. Workshop attendees were predominantly asset or performance managers or data specialists in their infrastructure organisations, or infrastructure-focussed academics. The workshop employed a trained facilitator and used a semi-structured experiencesharing discussion format. Preliminary discussions focussed on experiences of sand washout impacts on infrastructure assets, service provision and risk management challenges. After receiving experience sharing, initial results from early data analysis were shared with the workshop and feedback was received. Crucially, the workshop and interviews provided a framework for extracting infrastructure operators' perspectives on cross-infrastructure impacts of burst mains.

Detailed notes of the discussions were made as opposed to audio recordings because the experience of the authors has found that workshops can result in poor quality audio, which can be difficult to subsequently transcribe. Follow-up semistructured one-to-one interviews with workshop participants further explored particular issues of interest. Interviews were also held with local authority, rail and telecom representatives who were unable to attend the workshop, and notes 


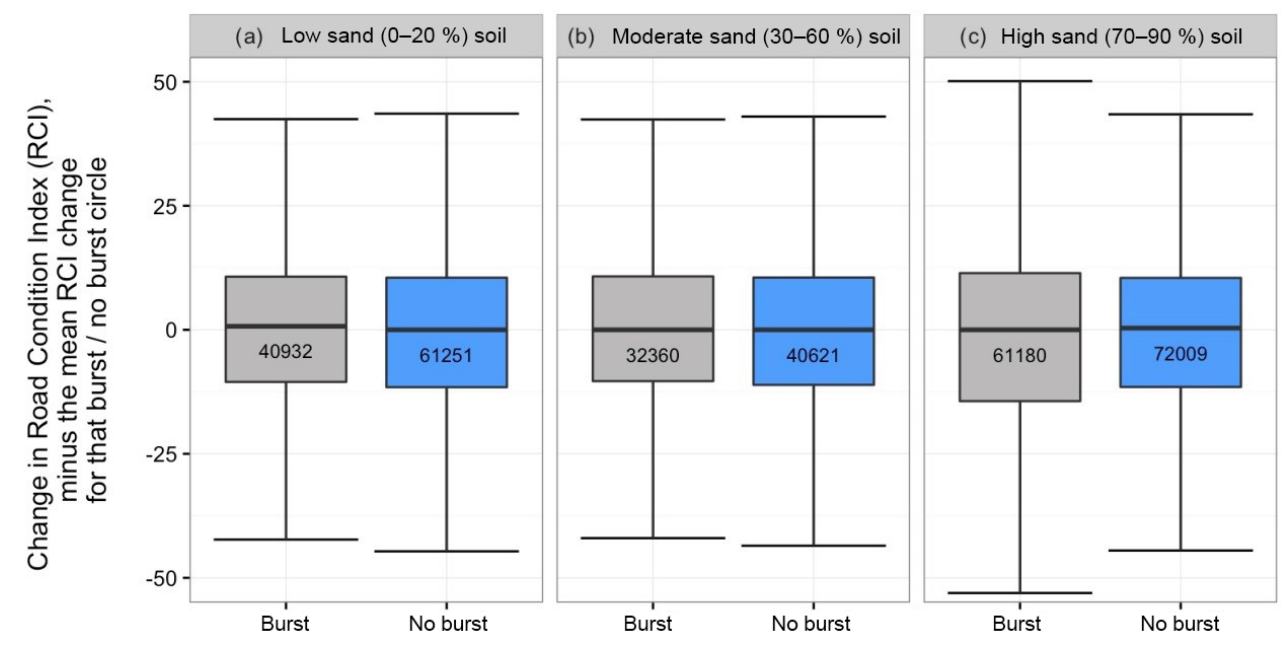

Figure 4. Comparison of the change in RCI before and after a burst water main (minus the mean RCI change for the circular sample area (Fig. 3). The numbers on the box plots represent the number of analysed road segments. Whiskers: range excluding outliers $(\mathrm{IQR} \pm 1.5 \times \mathrm{IQR})$.

or audio recordings of the discussions were collected. Established analytical methods were employed to analyse the workshop notes and interview transcripts, with an interpretive approach, based on inductive insights from the data used (Sadana, 2013). This involved the manual coding of the data, resulting in the inductive identification of key themes and sub-themes. Details from these discussions are illustratively incorporated in the results and discussions. For brevity, citations of comments from the workshops and interviews, and the meta-analysis media articles, are omitted from the discussion text.

\section{Results}

The results of the methods are briefly described below and in more depth in the Discussions. Where figures include error bars, they show the $95 \%$ confidence intervals for the Poisson mean. This interval is calculated by transforming a symmetric $95 \%$ confidence interval (CI) for the logarithm of the mean.

\subsection{Method 1 results: The impact of burst water mains on road surface quality}

In East Anglia (Fig. 1), $93 \%$ of minor (B) roads have pipes within $16 \mathrm{~m}$ of the centre line of the road. Thus, it is logical that a failure in the pipe network will impact directly on the road, through direct damage, subsurface void formation or indirectly through road cutting to access and repair the pipe. To test this, the change in road condition (RCI) was assessed (prior to and after a burst) using annual road condition surveys for $23289710 \mathrm{~m}$ road segments which were within $50 \mathrm{~m}$ of a burst main (potentially influenced) and 262140 segments which were between 50 and $100 \mathrm{~m}$ from the same bursts (deemed beyond influence of the burst) (Fig. 3).

The mean RCI change was approximately 0 (Fig. 4), with a consistent interquartile range (IQR) for all roads, except those within $50 \mathrm{~m}$ of a burst main and built on sandy (70\%$90 \%)$ soils. These showed greater spread in the change in road condition, which may indicate that greater remedial work is required to roads following a burst in sandy soils. Because of the large number of observations, the difference in the spread of the data is statistically significant. Even so, the difference in the spread is not very large, so while it does appear to support the scenarios of failure described in Sect. 3.1, caution should be applied to drawing strong conclusions from this analysis in isolation.

\subsection{Method 2 results: The impact of burst water mains on other water mains}

Using 50901 burst water main records, the spatio-temporal windows identified clusters for between $1 \%$ ( 1 day, $2 \mathrm{~m}$ radius) and $45 \%(365,100 \mathrm{~m}$ radius $)$ of the bursts. While the smallest spatio-temporal window shows low rates of cascade failure on sandy soils (annotation "a", Fig. 5) the converse is true for the largest spatio-temporal window (annotation "b"). In addition, the high rate of bursts for low sand content soils is apparent (annotation " $\mathrm{c}$ "). This may be indicative of common cause failures associated with clay soils (e.g. high corrosivity or shrink-swell potential). These clusters in the low sand content soils increase with expanding spatio-temporal windows, reflecting the larger number of bursts in these corrosive and movable soils. The bursts data used only show independent repairs, so jobs to repair previous repairs which have failed prematurely are excluded. 


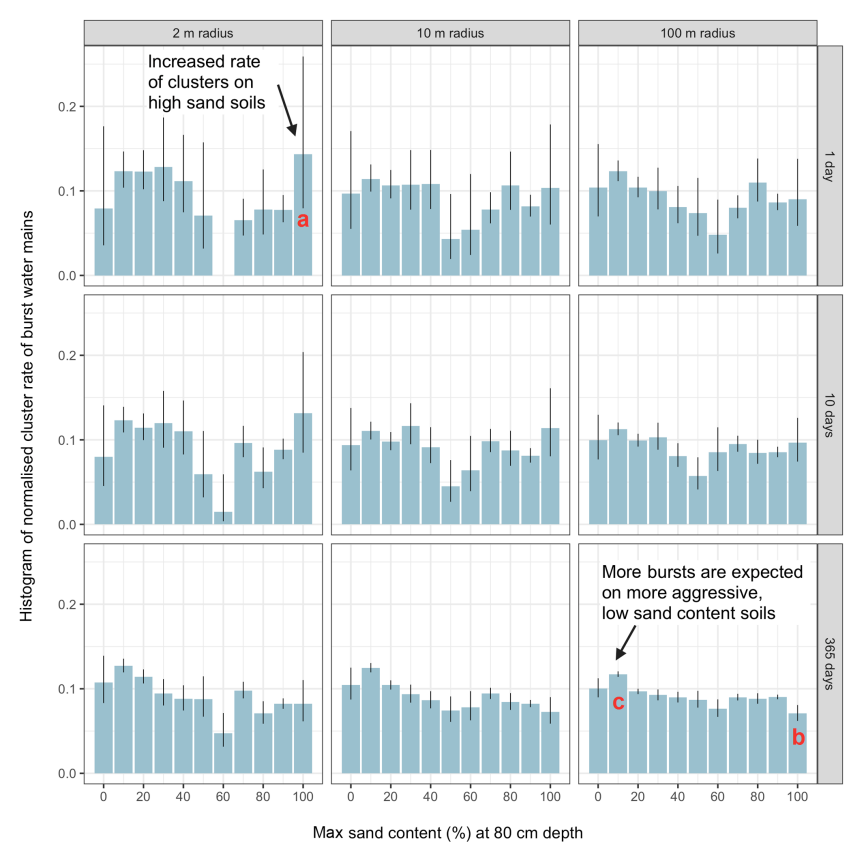

Figure 5. Normalised rate of burst cluster/all bursts, within expanding spatio-temporal windows, by maximum soil sand content at $80 \mathrm{~cm}$ depth. Error bars: $95 \%$ confidence interval for the Poisson mean. Higher bars indicate more clusters of bursts per initial trigger burst. For clarity, only 9 of the 25 spatio-temporal windows are shown.

\subsection{Method 3 results: The impact of burst water mains on other infrastructure and society}

The meta-analysis of media reports identified 33 multiinfrastructure events across England and Wales between 2009 and 2017 (locations plotted in Fig. 2, and summarised in Appendix A). The articles provided detailed information on the impacts of burst mains on infrastructure and wider society (e.g. school and hospital closures, length of traffic delays, amount of bottled water delivered and the emotions of those impacted by the events). The impacts of burst water mains on infrastructure and wider society are summarised in Fig. 6 and Table 1. Co-located roads and gas pipes were the most commonly affected infrastructure.

The overall rate of bursts is only slightly controlled by soil sand content. For example, the rate for the bands in Fig. 7 only ranges from 0.97 to 1.05 bursts per kilometre. However, the meta-analysis of the media reports indicated that sand content does play a controlling role in the likelihood that an initial burst will go on to impact other infrastructure or wider society. A substantially higher rate of media-reported cascading infrastructure failures was observed in sandy soils (Fig. 7).
Table 1. Summary of impacts on other infrastructure from burst water mains (from analysis of media reports). Where reports indicate a range (e.g. 8-11), this is due to uncertainty in the descriptions provided by the article.

\begin{tabular}{lll}
\hline Infrastructure & Reports & Impacts \\
\hline Road & 21 & $\begin{array}{l}\text { Flooding, surface damage, sink- } \\
\text { holes }( \pm \text { vehicles in them), traffic } \\
\text { delays, closure. }\end{array}$ \\
\hline Houses & 10 & $\begin{array}{l}\text { Loss of water, loss of gas, flood- } \\
\text { ing, sewage flooding, evacuation, } \\
\text { subsidence, extensive cracking. }\end{array}$ \\
\hline Gas & $8-11$ & $\begin{array}{l}\text { Loss of gas, fractured pipe, water } \\
\text { and sediment in gas } \\
\text { mains }\end{array}$ \\
\hline
\end{tabular}

$\begin{array}{lll}\text { Buildings } & 6 & \text { Flooding of county hall, schools }\end{array}$
closed, hospital wards and accident and emergency $(\mathrm{A}+\mathrm{E})$ department closed and patients transferred. Shops closed. Lamp posts unstable.

\begin{tabular}{lll}
\hline Sewers & 3 & $\begin{array}{l}\text { Blocked sewers leading to foul } \\
\text { flooding. Pumping station filled } \\
\text { with sand. Tankers required to } \\
\text { pump sewage. Sewer collapse. } \\
\text { Raw sewage in garden. }\end{array}$ \\
\hline Health & 3 & $\begin{array}{l}\text { Health suffering due to cold ex- } \\
\text { posure. Sewage in gardens. A+E } \\
\text { closed, and patients moved. Toi- } \\
\text { lets out of action. }\end{array}$ \\
\hline Electric & $2-5$ & $\begin{array}{l}\text { Loss of electronic payments. Fa- } \\
\text { cilities unable to open. }\end{array}$ \\
\hline Water & $2-3$ & $\begin{array}{l}\text { Loss of water, second pipe repair } \\
\text { in close proximity. }\end{array}$ \\
\hline Telecoms & 2 & $\begin{array}{l}\text { Loss of phone and internet ser- } \\
\text { vices (including no credit card } \\
\text { payments at a supermarket for } \\
\text { many hours). }\end{array}$ \\
\hline
\end{tabular}

\subsection{Method 4 results: Cross-infrastructure workshop and $1: 1$ interviews}

The workshop and interviews provided many detailed insights into the hidden costs and pressures arising from burst water mains. These impacts are also included in Fig. 6 and aspects are described in more depth in the Discussion section. 


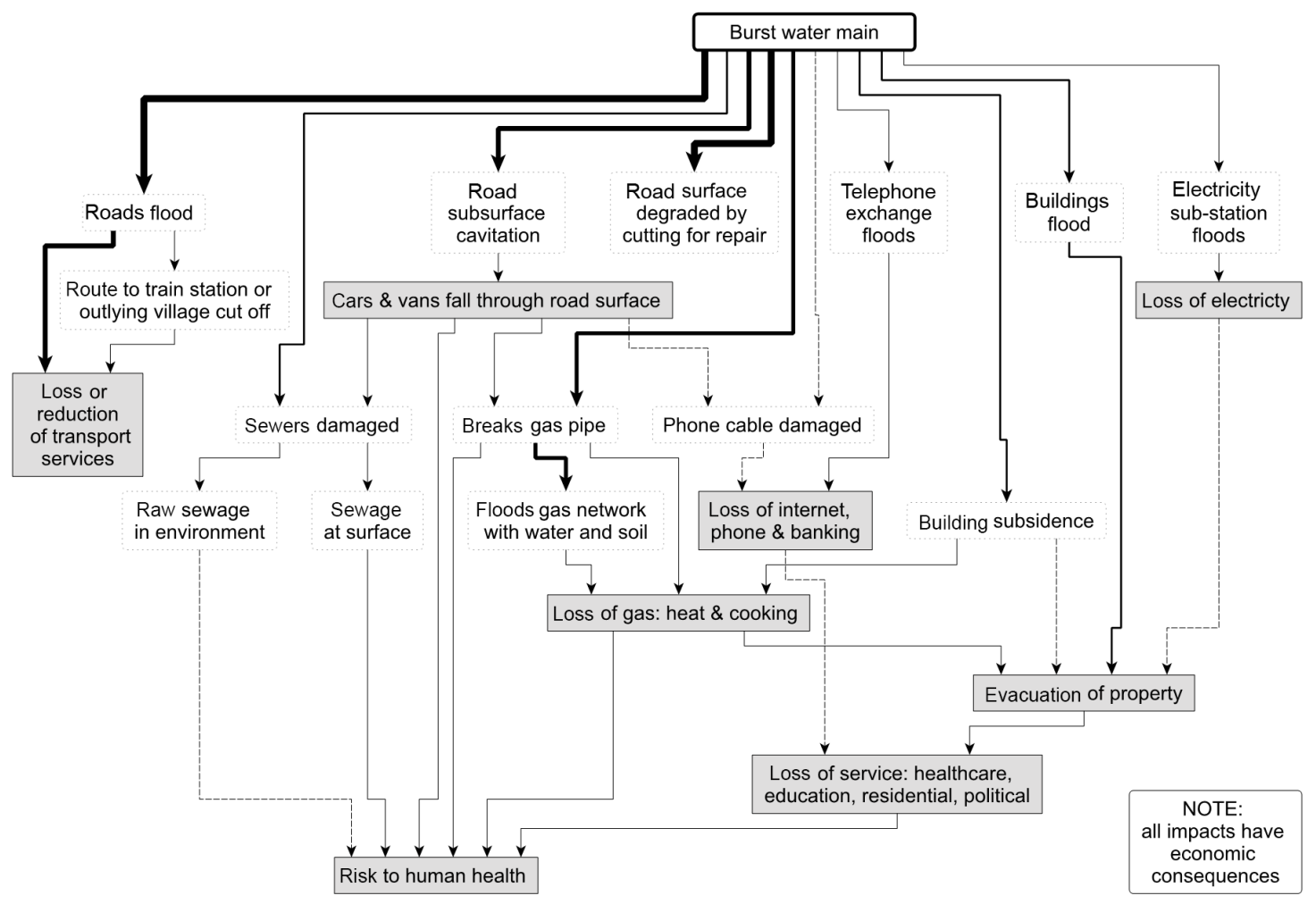

Figure 6. Summary of impacts from burst water mains on other infrastructure and wider society. Schematic diagram based on analysis of 33 media reports, workshop discussions and interviews, showing impacts on other infrastructure and society. Line width represents the relative frequency of the impact.

\section{Discussion}

This section combines discussions from all the methods. Method 1 explored the impact of bursts on road surface quality, and Method 2 looked at the spatio-temporal clusters of bursts by sand content. Limitations in the quantity, consistency and spatio-temporal accuracy of other infrastructure failure datasets did not allow cluster analysis for other infrastructure types. Method 3's media meta-analysis and the workshop/interviews of Method 4 revealed insights into the wider impacts of water mains on other infrastructure that were hidden from Method 1's and 2's spatial data analysis of industry-reported failures. The media articles provided in-depth details on the wider impacts on society (families, schools, businesses etc.), albeit in a more sensational and qualitative manner than other reporting methods. The workshop and interviews provided the behind-the-scenes views from infrastructure operators on how large failure events impact service delivery and repair processes. In the workshop, network operators described cross-infrastructure failures as low-frequency but moderately high-impact events. The importance, and difficulty, of cross-infrastructure communication and co-working was identified (Dawson et al., 2016). The value of cross-sector regional task groups was asserted and many impacts on other infrastructure networks were dis- cussed. Below, highlights of some of the common impacts on key UK infrastructure types from burst water mains are provided. This is followed by a discussion on the impact of burst mains on wider society and the implications of this work for risk management. Finally, a brief discussion of the performance of the mixed-methods approach is provided.

\subsection{Roads}

Flooding and damage to roads are common direct impacts from co-located pipes (Table 1, Appendix A). Void formation under the road surface can also impact safety (e.g. vehicles falling through the road surface into voids). Minor and local roads are more likely to be impacted by water mains failures than major roads, as minor roads are more commonly underlain by water pipes and have a level of engineering reflective of the lower levels of traffic. However, examples where major roads have been impacted include a burst-formed void under a road in Kent costing a water company GBP 640000 in remediation, and causing a 25-day road closure. Burst mains have also flooded motorways, causing significant disruptions.

Bursts in sandy soils appear to be slightly more likely to change the road surface condition than bursts in other soil types (Fig. 6). Even if the road is not damaged by the burst 


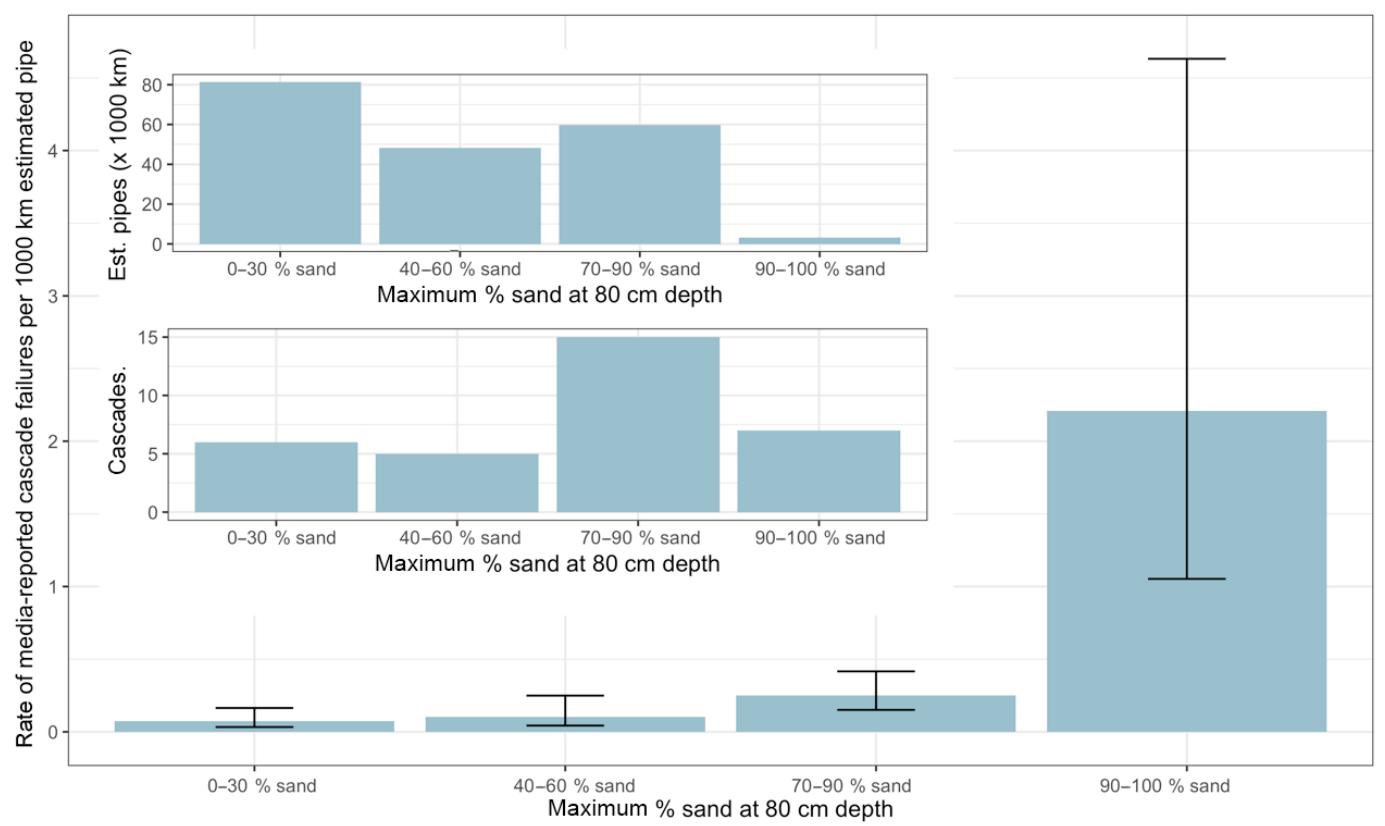

Figure 7. Main figure: rate of media-reported cascade failures, normalised by estimated pipe length in each soil type. Error bars: $95 \%$ confidence interval for the Poisson mean. Top inset: estimated pipe length across England and Wales, by sand content. Bottom inset: number of media-reported cascade failures, by sand content.

and water pressure, pipe repairs commonly require cutting of the road surface to access the failed pipe. Highway authorities within England and Wales report that such cutting and trenching impacts the structural integrity of the road, and potentially reduces the road's service life by $30 \%$ (Asphalt Industry Alliance, 2016). This was also reported independently at the workshop and in the interviews. Cuts to the road surface represent physical lines of weaknesses in a previously solid, load-bearing surface, as well as the subsurface. Cuts and trenches are well known to lead to subsequent potholes or surface deformation features, including differential settlement. It was reported by highway engineers that cut roads not only have a shorter service life, with higher maintenance costs, but also that cuts may be contributory factors to subsequent water pipe failures at the same location.

Where cavitation occurs over an extended period of time (due to a small water leak from mains, or frequent infiltration/exfiltration of sewers), a commonly reported symptom is road profile change, which can provide an early warning of issues beneath the road. Multiple media reports described how small road surface deformations were initially misdiagnosed and treated as simple surface failures, only for a larger deformation or hole to appear the next day.

\subsection{Ports and railways}

Ports and railway stations represent critical access nodes for international and national transport. The vulnerability of the access routes to the ports of Felixstowe and Lowestoft was discussed in the workshop, as parts of these key transport routes are on sandy soil. If access roads are closed due to cavitation from a burst main (or tidal surge, as occurred outside the Lowestoft train station in 2014), then access to the ports/railway would be severely restricted. The economic and transport consequences of port closures are severe. As well as preventing access to these transport nodes, burst mains can also affect railway infrastructure itself. In August 2016, a burst water main contributed to the collapse of a railway embankment and bridge in Leicestershire, disrupting rail journeys for thousands of passengers for a number of days.

\subsection{Gas distribution pipes}

Gas pipes can be damaged by water mains as a result of (1) the pressure of the water itself, (2) water and soil mixed to an abrasive "sandblasting" slurry or indirectly through (3) cavitation and subsequent damage by vehicles or road surface collapse. Such failures commonly cause many hundreds of houses to lose their gas supply (Appendix A).

The cost of repairs to gas pipes is reported to be insignificant compared to the cost of removing water and sediment from gas pipes. In some reported cases, up to $10000 \mathrm{~L}$ of water and debris needed to be pumped from the gas network. Removing water and sediment is a complex process leaving properties without gas for extended periods of time. In one burst-triggered gas network failure, supplies to 250 customers were lost for 7 days due to the valveless low-pressure gas networks. These pipes required repeated digging (each 
time damaging the road) to (1) insert a camera to find the blockages, (2) isolate the main, and then (3) physically isolate each property. There are additional regulator-imposed charges associated with loss of service and potential health risks for vulnerable people due to a lack of heating.

Workshop discussions also highlighted that health risks are higher when, following a leak, gas enters a building. This most often occurs through migration of gas through the soil into houses, but also can occur when water enters a damaged gas main. As more water enters the pipe, the gas pressure will drop for short periods to a point at which some pilot lights on domestic boilers can extinguish, leaving gas entering into unlit boilers. These types of failures are reported to be hard to predict. Gas meters and boiler valves can also be damaged by water and debris in the network, which bears additional repair costs.

\subsection{Buildings and houses}

Public and private buildings are commonly impacted by water mains failures, both directly (e.g. flooding or subsidence) and indirectly through loss of services. In one burst near Bristol, 8000 homes lost water supply for 3 days (Appendix A; BBC, 2014a). Properties can also lose gas supply or expose residents to risks. In one example, 25 homes were evacuated due to a large gas leak. When sewers are blocked due to sediment ingress, sewage can enter houses through the toilets. Property subsidence has also been reported following a burst main near a house on sandy soil as a result of cavitation. This led to cracks opening up in the walls in the winter and health impacts for the vulnerable residents were reported.

\subsection{Other water mains}

While multiple water mains failures were only specifically reported three times in the media analysis, the GIS cluster analysis identified that $2 \%-3 \%$ of bursts were co-located with another burst within $5 \mathrm{~m}$ and 5 days of the original burst. For clusters within $2 \mathrm{~m}$ and 1 day, a slightly higher rate of failure was observed for pipes in the sandiest soils (Fig. 5, annotation "a"). A water company reported higher rates of multiple pipe failure due to sand abrasion for softer polyethylene pipes than metallic pipes. Subsequent research could repeat this method by looking at each pipe material (e.g. cast iron, asbestos cement, $\mathrm{PVC}$, polyethylene) in isolation to highlight the impact of sand abrasion on the different pipe materials.

\subsection{Sewers}

Sewer impacts from burst mains include physical damage to the sewer, leading to blockages and flooding by sewage of roads and gardens. Such incidents are unpleasant and carry associated health risks. When properties lose sewerage, tankers are required. As sewers do not require the same structural integrity as gas and water mains and have joints every few metres, they are vulnerable to exfiltration of sewage and infiltration of water and particles. The change between high and low external pressures can lead to void formation around the sewer. Increased water pressures can come from burst mains and natural events such as storm surges or high rainfall events. Due to their non-cohesive texture, sandy soils are more likely to be washed into the sewers than clays and loams.

A water company that manages both water distribution and sewerage networks reported that voids in sandy soils around sewers are more problematic than around mains pipes. When reported, voids can be filled with a resin. If left unchecked, the structural integrity and flow pathways of the sewer can suffer as the sewers settle into the void. This in turn can increase the probability of a subsequent blockage, which can in turn lead to sewer flooding.

\subsection{Electrical distribution}

Flooding from burst mains is a potential risk to urban electricity infrastructure, where substations and electrical equipment are commonly located in basements or underground recesses. One below-ground substation was reported to have suffered two floods in 2 years resulting in GBP 1 million costs and subsequent relocation of equipment. Any disruption to electricity supply can have wide impacts, including to IT networks.

Impacts on electricity distribution networks from sand washout events were less frequently identified, with $12 \%$ of media reports mentioning electricity distribution impacts. An electrical distribution network operator attributed this low impact rate to buried electricity cables having sufficient flexibility to accommodate a loss of ground support and that the higher voltage cables were buried at greater depth. However it was reported that older forms of lead-covered, paperinsulated cables exhibit limited flexibility and are thus more vulnerable. Another reason for the resilience of the electricity networks is that they are reconfigurable, with supplies rarely interrupted for more than a few seconds, anywhere other than single-source nodes of the network.

Electric cables are most commonly damaged by "third party strikes" when water companies and gas companies dig down to repair or replace their assets. Notable advances have been made by utilities to avoid these strikes and the associated risk to human life, and additional damage, but they still do occur as the electric cables often sit on top of water mains.

\subsection{Telecom cables}

Telephone cables appear resilient to burst main impacts, possibly due to the prevalence of overhead lines in older residential areas (so co-location is not an issue). Only one example of a burst main resulting in telephone disruption was categorically identified by the media analysis. However, in this instance, when the phone lines were cut off, a very large 
supermarket was prevented from accepting credit card payments until the lines were repaired.

\subsection{The impacts of burst water mains on wider society}

The socio-economic implications of burst mains range from simple repairs of the infrastructure to more complex impacts such as increased travel times, loss of work and disruption to businesses through loss of footfall or disruptions to electronic payments. If roads serving isolated communities are closed, the impact of even a week of lost earnings can be catastrophic for small businesses. Schools and hospitals (and many businesses) cannot open without water, and numerous examples of such closures were identified. When schools close, there is a subsequent impact on the local economy as many parents cannot attend work that day.

Whilst health is rarely affected directly by burst mains, secondary impacts were identified. Examples include closure of hospital units and the movement of vulnerable patients to other hospitals, raw sewage in gardens and subsidence leading to the formation of cracks in houses with associated heat loss and implications for the health of older residents. When gas mains are ruptured, houses may be evacuated to minimise health impacts. When cars become trapped in holes in the road there is potential for significant injury or death. While it is the duty of infrastructure operators to minimise risk, there are also longer term socio-economic and liability costs if human health is affected. Furthermore, any major disruption to infrastructure service provision can result in public relations and customer satisfaction impacts.

Road damage or flooding can extend travel times and distances and can result in reputational damage to the water and highway operators. Diversions in rural areas of up to $48 \mathrm{~km}$ were identified in the media analysis. Major voids will lead to longer road closures and greater socio-economic impacts.

\subsection{Implications of this research for risk management}

Sand washout is not the most common, or damaging, soilrelated geohazard (Pritchard et al 2014a). However, due to the distribution of sandy soils (Fig. 1), regional trends can be observed. While some local authorities (particularly those in sandy soil areas) have dedicated teams to address this issue, most utilities only deal with these events on a case-by-case, reactive, basis. Although some of the impacts of these events have been considerable, it was noted by infrastructure operators that their low frequency make them difficult to consider as part of many asset management plans.

Monitoring of infrastructure stability can incur substantial costs and is often unfeasible across an entire network, so reactive responses to infrastructure failures are common. Nevertheless, it was noted that the use of soil maps and other geohazard datasets to identify assets and communities at risk from washout and other events would be a first step most infrastructure organisations could take to identify (and then potentially mitigate) their exposure to these risks. Such maps can inform decision-making, help prioritise areas for increased levels of maintenance or faster response times and to inform asset management plans.

The infrastructure-provided failure data analysed did not provide the severity or scale of the impact. One burst main may cost a nominal amount to repair, but one which impacts on other infrastructure systems can have significant costs associated. Each burst, irrespective of its impact, is currently represented by one record each in the company bursts database. Utilities may wish to record the severity and scale/cost of the impact in their relational spatial databases to identify areas of their network which commonly are more expensive to fix. The importance of collecting and maintaining highly accurate spatial data for assets and failures is asserted, if later data analysis is to be undertaken and meaningful results provided to inform future decision-making.

Information sharing around infrastructure interdependencies between utilities is often only undertaken on a "need to know" basis. This is particularly true where issues of commercial confidentiality and/or national security apply, for example to national critical infrastructure. Because of a focused remit on their own infrastructure, low levels of information sharing on environmental hazards and risks occurs even between similar networks in the same geographic region. However, many countries are seeing a transition towards large parent companies owning multiple utility companies (e.g. in the UK, Cheung Kong Infrastructure Holdings Limited largely owns Northern Gas Networks, Northumbrian Water and UK Power Networks, and also owns a strategic stake in the Southern Water Group). As a result, where appropriate, information sharing between these companies operating in the same area is encouraged by the parent company. Independent operators working in similar regions may take part in local infrastructure groups or national infrastructure resilience networks.

Many utilities stated that their awareness of systemic vulnerabilities, risks and interdependencies was less than ideal, and expressed their desire to better understand the societal risks beyond that of their own network concerns and liabilities. A desire for greater quantification of the impacts of these type of low-frequency events on levels of service and resilience was expressed, as the predominant focus is on the reduction of high-likelihood, high-impact risks. While this research begins to address these desires, there is potential for a more thorough analysis of these types of failures, using and building on the approaches used in this research. UK-wide data on water mains bursts are being collected in the National Failures Database, held by the UK Water Industry Research Organisation. Similar databases for other infrastructure communities would be of value. The consideration of lower likelihood, moderate-impact risks is being encouraged by the UK water regulator Ofwat in their Resilience in the Round documentation (Ofwat, 2017) 


\subsection{Assessments of the mixed-methods approach}

This scoping study sought to describe and begin to quantify the impacts of burst mains on other infrastructure and society. A mixed-methods approach, rather than a pure GIS data analysis of reported infrastructure faults and failures, was used, and the value of the details provided by the meta-analysis of media reports and expert knowledge distilled from workshops and interviews quickly became apparent.

The spatial data analysis quantified the control of soil on the impacts of burst mains on road surface quality (Method 1) and on the likelihood of subsequent bursts (Method 2). However, the unavailability and/or inaccuracy of many infrastructure datasets did not permit the desired identification of many cascading infrastructure failures in this approach. While data are now being collected on the duration and number of properties impacted by water supply interruptions, the industryreported burst data used in this research data did not describe wider societal impacts, nor the scale or cost of the failures. The industry GIS data were usually restricted to the location, date and repair type undertaken. In contrast, the metaanalysis of media reports (Method 3, impacts summarised in Appendix A) provided qualitative descriptions of both infrastructure failures and the impacts on health, economy and people. Because media reports tend to focus on the larger bursts, the impacts are not representative of all bursts. However, analysis of these reports identified that the rate of these dramatic failures per $1000 \mathrm{~km}$ pipes is higher in areas of sandy soils (Fig. 4). Because of the depth of information gleaned from this approach, media meta-analysis is encouraged for other studies of low-frequency, moderate-impact local environmental risks. Further work on the removal of any spatial bias from such reporting is recommended. Social media feeds may also serve as a crowdsourced dataset for identifying these types of failure. The workshop and one-to-one interviews with infrastructure owners and operators (Method 4) captured detailed perspectives on these cascading infrastructure failures and their impact on service delivery, costs, responses and management plans. The combination of these methods led to more quantifiable, descriptive and useful results than would have been possible if each method was used in isolation.

\section{Conclusions}

Diverse examples of the cross-infrastructure impacts from burst water mains have been identified and discussed. Cascading infrastructure failures, while occurring in many soil types, appear to be more than 3 times as common in soils with high sand content (Fig. 7). While the investigations undertaken in this research have focussed on areas within the UK, the same principles will apply in any country where sandy soils are present (e.g. Majid et al., 2010). The types of failures described tended to be low-frequency, moderate- impact events. Due to asset co-location, roads and gas pipes are the infrastructures most commonly affected by burst water mains (Fig. 6). There are substantial direct and indirect economic costs of these events.

The impact of burst water mains on other infrastructure can be long-lasting (e.g. reduction in the structural integrity of a road) or costly to repair (e.g. removing water and sediment from a flooded gas network). Burst mains can also impact on the wider society, disrupting healthcare, increasing travel times or closing local businesses, government operations and schools. The costs of these societal impacts are rarely quantified and are typically borne by affected individuals. Wider discussions around cascading failures are of relevance to regional infrastructure and resilience groups.

The research illustrates the potential value of mixedmethods approaches to investigate such complex infrastructure hazards and risks. The geospatial data analysis of infrastructure failures provided insufficient information to fully address questions about the impact of burst mains on proximal infrastructure and society. In contrast, the meta-analysis of local news stories provided rich information relating to the cascading impacts of burst water mains. Furthermore, the direct input from infrastructure operators through the workshop and interviews obtained valuable information on their views on these risks to their infrastructure resilience. Thus, the authors believe that mixed-methods approaches holds great potential for infrastructure research, but such approaches do require careful development and evaluation. To benefit more from these approaches, infrastructure operators are encouraged to improve the spatio-temporal accuracy of their failure/condition mapping and the speed to which the data on these failures are made available throughout the company.

Marker (1998) argued that earth science is generally underused in spatial planning. Twenty years later, the comment can be restated. Soil maps, similar to those used in this research, can help infrastructure companies identify assets in soils vulnerable to sand washout and other more common soil-related geohazards (Pritchard et al., 2014a). Clear identification of the hazards present in a local area will enable informed decision-making. Vulnerable assets can be identified, assessed and repaired or proactively replaced to minimise cascading impacts.

Data availability. This study reanalysed data from a number of sources, with varying levels of accessibility. The details of the media-reported multi-infrastructure failures are provided in Appendix A. The soil data are available under licence at http://www.landis.org.uk (Cranfield University, 2018). The road data are openly accessible at https://www.ordnancesurvey. co.uk/business-and-government/products/os-open-roads.html (OS, 2016). Due to the commercially sensitive nature of the infrastructure data, it is not openly accessible. Enquiries regarding the data generated in this study should be sent to researchdata@cranfield.ac.uk. 


\section{Appendix A}

Table A1. Summary of the media-reported multiple infrastructure failures. Sand \% is the maximum soil sand content at $80 \mathrm{~cm}$ depth.

\begin{tabular}{|c|c|c|c|c|}
\hline ID & Date $(\mathrm{d} / \mathrm{m} / \mathrm{yr})$ & Sand $\%$ & Summary of media report & URL \\
\hline 1 & $23 / 02 / 2009$ & 93 & $\begin{array}{l}15 \mathrm{~cm} \text { PVC main burst. Damaging road surface. Po- } \\
\text { lice involved. } 69 \text { houses off water. Fire engine called } \\
\text { to pump water. Bottled water supplied. Took } 20 \mathrm{~h} \text { to fix } \\
\text { pipe. }\end{array}$ & $\begin{array}{l}\text { http://www.northnorfolknews.co.uk/news/cromer_ } \\
\text { water_main_fixed_1_533520 (Hamilton, 2009) }\end{array}$ \\
\hline 2 & $02 / 11 / 2009$ & 80 & $\begin{array}{l}\text { A main road and footpath in Lincoln are closed for } 2 \\
\text { days after a burst water main. }\end{array}$ & $\begin{array}{l}\text { http://news.bbc.co.uk/1/hi/england/lincolnshire/ } \\
\text { 8337851.stm (BBC, 2009) }\end{array}$ \\
\hline 3 & $06 / 10 / 2011$ & 95 & $\begin{array}{l}\text { Burst main - car fell through road. Closed road leading } \\
\text { to gridlock. } 100 \mathrm{~m} \text { of road to be reinstated. } 30 \mathrm{~cm} \text { main. } \\
\text { Road closed for } 3-4 \text { days. Water supplies off. }\end{array}$ & $\begin{array}{l}\text { http://www.getsurrey.co.uk/news/local-news/ } \\
\text { burst-water-main-leaves-gaping-4813168 } \\
\text { (getSurry, 2011) }\end{array}$ \\
\hline 4 & 27/09/2012 & 95 & $\begin{array}{l}\text { Ground collapsed under car, driver missed work. Lamp } \\
\text { post unstable, electic supply isolated. Water supplies to } \\
\text { area affected. Schools in Chertsey and Woking closed. } \\
\text { Centre for disabled kids and adults closed. Extensive } \\
\text { damage to roundabout, } 3 \text {-4-day closure. } 38 \mathrm{~cm} \text { main. }\end{array}$ & $\begin{array}{l}\text { http://www.getsurrey.co.uk/news/local-news/ } \\
\text { video-ground-just-collapsed-under- } 4809243 \\
\text { (Morris, 2012) }\end{array}$ \\
\hline 5 & $10 / 10 / 2012$ & 87 & $\begin{array}{l}\text { Burst water main. Void formation - driveway collapse } \\
\text { and household subsidence. Cold air coming through } \\
\text { cracks, with claimed health impacts. Insurance loss ad- } \\
\text { justors and legal representatives will be agreeing the } \\
\text { next steps. }\end{array}$ & $\begin{array}{l}\text { http://www.worcesternews.co.uk/news/10354380.We_ } \\
\text { re_scared_our_houses_are_collapsing/ (Broome, 2012) }\end{array}$ \\
\hline 6 & $20 / 12 / 2012$ & 47 & $\begin{array}{l}\text { Burst main. Closed road to facilitate repairs. Also dam- } \\
\text { aged electricity duct. Found second water leak. Interim } \\
\text { repair first, and full repair in a few weeks. }\end{array}$ & $\begin{array}{l}\text { http://www.worcesternews.co.uk/news/10120224. } \\
\text { Road_is_reopened_after_leak_in_pipes/ } \quad \text { (Worcester } \\
\text { News, 2012) }\end{array}$ \\
\hline 7 & $06 / 04 / 2013$ & 23 & $\begin{array}{l}\text { Burst main forms a void under road into which a Severn } \\
\text { Trent van falls, cracking a gas pipe and leading to the } \\
\text { evacuation of } 25 \text { homes. Tens of thousands of pounds of } \\
\text { flood damage. Roads closed for many days. Local coun- } \\
\text { cil records flooding and offices closed for many days. }\end{array}$ & $\begin{array}{l}\text { http://www.bbc.co.uk/news/ } \\
\text { uk-england-derbyshire-22050687 (BBC, 2013b) }\end{array}$ \\
\hline 8 & $26 / 04 / 2013$ & 11 & $\begin{array}{l}\text { Burst main closes main road in Swindon for many days. } \\
30 \mathrm{~m} \text { of road surface damaged by burst main }(30 \mathrm{~cm}) \text {. }\end{array}$ & $\begin{array}{l}\text { http://www.bbc.co.uk/news/ } \\
\text { uk-england-wiltshire-22312127 (BBC, 2013a) }\end{array}$ \\
\hline 9 & $01 / 11 / 2013$ & 92 & $\begin{array}{l}\text { Burst main (caused by BT contractors). Floods } 90 \\
\text { homes, } 9 \text { flats and retirement homes. Fire crews in- } \\
\text { volved - bottled water supplied. } 30 \text { gas company staff } \\
\text { involved. Gas supplies cut to } 86 \text { homes, removed } \\
10000 \mathrm{~L} \text { of water from the gas network. Lots of sand } \\
\text { in pipes too - complex engineering process to vacuum } \\
\text { out the pipes. Heating equipment given out. }\end{array}$ & $\begin{array}{l}\text { http://www.getsurrey.co.uk/news/local-news/ } \\
\text { river-running-down-road-burst-6263464 (Martin, } \\
\text { 2013) }\end{array}$ \\
\hline 10 & 06/01/2014 & 87 & $\begin{array}{l}\text { 100-year-old large burst main - thousands of people off } \\
\text { water. Significant road damage (A6). Road closed for } \\
\text { more than a week. Busy commuter route near M1. }\end{array}$ & $\begin{array}{l}\text { http://www.bbc.co.uk/news/ } \\
\text { uk-england-leicestershire-25619109 (BBC, 2014a) }\end{array}$ \\
\hline 11 & $16 / 01 / 2014$ & 87 & $\begin{array}{l}\text { Huge pipe burst. Vast amount of water - flooding area } \\
\text { the size of a football pitch. Brown water in supply. Sec- } \\
\text { ond time in } 10 \text { days this area has been impacted by burst } \\
\text { main. }\end{array}$ & $\begin{array}{l}\text { http://www.bbc.co.uk/news/ } \\
\text { uk-england-leicestershire-25757918 (BBC, 2014e) }\end{array}$ \\
\hline 12 & $21 / 03 / 2014$ & 95 & $\begin{array}{l}\text { Burst main. Flooding driveways and gardens. Traffic } \\
\text { delays. }\end{array}$ & $\begin{array}{l}\text { http://www.getsurrey.co.uk/news/surrey-news/ } \\
\text { gardens-drives-flooded-after-a320-6860355 } \\
\text { bot, 2014) }\end{array}$ \\
\hline 13 & 09/04/2014 & 95 & $\begin{array}{l}38 \mathrm{~cm} \text { main burst. Traders, charities and community } \\
\text { centres closed, especially those with toilets, and cafes. } \\
\text { Delays to repair of water supply because of a large elec- } \\
\text { tronic sign in a concrete plinth with a power cable ris- } \\
\text { ing through the middle, requiring specialist teams. Res- } \\
\text { idents requested not to use dishwasher or washing ma- } \\
\text { chines to preserve water in tanks. }\end{array}$ & $\begin{array}{l}\text { http://www.getsurrey.co.uk/news/surrey-news/ } \\
\text { woking-loses-water-supply-due-6941235 } \\
\text { (Harper, 2014) }\end{array}$ \\
\hline 14 & $13 / 04 / 2014$ & 64 & $\begin{array}{l}\text { Car stuck in hole on A320. No disruption to water sup- } \\
\text { ply. Water company paying car insurance claim. Resur- } \\
\text { facing road. Road closed for } 1 \text { day. Police closed road. } \\
38 \mathrm{~cm} \text { main. }\end{array}$ & $\begin{array}{l}\text { http://www.getsurrey.co.uk/news/surrey-news/ } \\
\text { car-becomes-lodged-burst-water-6983196 (Morris, } \\
\text { 2014) }\end{array}$ \\
\hline
\end{tabular}


Table A1. Continued.

\begin{tabular}{|c|c|c|c|c|}
\hline ID & Date $(\mathrm{d} / \mathrm{m} / \mathrm{yr})$ & Sand $\%$ & Summary of media report & URL \\
\hline 15 & $17 / 04 / 2014$ & 64 & $\begin{array}{l}\text { Another car in A320 hole. } 38 \mathrm{~cm} \text { Victorian main. Local } \\
\text { traffic congestion. PR issues now because of repeated } \\
\text { problems with cars falling through roads. }\end{array}$ & $\begin{array}{l}\text { http://www.getsurrey.co.uk/news/surrey-news/ } \\
\text { affinity-water-continue-patchwork-repairs-7000547 } \\
\text { (Butt, 2014) }\end{array}$ \\
\hline 16 & $12 / 06 / 2014$ & 88 & $\begin{array}{l}1.2 \mathrm{~m} \times 1.2 \mathrm{~m} \text { void under road. Not sure if it is caused } \\
\text { by gas leak, or if the void caused the gas leak. Road } \\
\text { closed for a number of days. Gas smelled for a month } \\
\text { before the hole was discovered. }\end{array}$ & $\begin{array}{l}\text { http://www.getsurrey.co.uk/news/surrey-news/ } \\
\text { road-closure-after-sinkhole-appears- } 7259207 \\
\text { (Martin, 2014) }\end{array}$ \\
\hline 17 & $22 / 08 / 2014$ & 39 & $\begin{array}{l}\text { Burst main breaks gas pipes and flooded gas network. } \\
755 \text { properties with no heating or hot water for days. } \\
100000 \mathrm{~L} \text { of water removed so far. } 150 \text { properties off } \\
\text { gas for extended period. Distributing fan heater and } \\
\text { warming plates. Working with local authority social ser- } \\
\text { vices. Washing facilities for people provided by sports } \\
\text { centres. }\end{array}$ & $\begin{array}{l}\text { http://www.walesonline.co.uk/news/local-news/ } \\
\text { gas-disruption-nantyglo-leaves-hundreds-7660937 } \\
\text { (Bevan, 2014) }\end{array}$ \\
\hline 18 & $26 / 09 / 2014$ & 23 & $\begin{array}{l}\text { Large diameter main }(76 \mathrm{~cm}) \text { burst. } 8000 \text { homes without } \\
\text { water. } 18 \text { schools closed. Bristol Water and Red Cross } \\
\text { handing out water. } 19 \text { people rescued by dinghy, and } \\
\text { spent the night in a church hall. Huge hole in road. Gar- } \\
\text { dens destroyed. }\end{array}$ & $\begin{array}{l}\text { http://www.bbc.co.uk/news/ } \\
\text { uk-england-bristol-29373980 (BBC, 2014b) }\end{array}$ \\
\hline 19 & $28 / 09 / 2014$ & 95 & $\begin{array}{l}\text { Burst main floods gas pipe. } 650 \text { houses off gas. } 80000 \mathrm{~L} \\
\text { of water removed from gas network. Significant dam- } \\
\text { age to gas meters and appliances. Gas company sup- } \\
\text { plied electric hobs and heaters to affected homes. Set } \\
\text { up a customer centre at the local church. }\end{array}$ & $\begin{array}{l}\text { http://www.bbc.co.uk/news/ } \\
\text { uk-england-dorset-29362291 (BBC, 2014d) }\end{array}$ \\
\hline 20 & $30 / 09 / 2014$ & 0 & $\begin{array}{l}\text { Burst main floods gas network. } 297 \text { houses off gas. } \\
200 \text { homes off water. Heaters and portable cookers pro- } \\
\text { vided. }\end{array}$ & $\begin{array}{l}\text { http://www.examiner.co.uk/news/west-yorkshire-news/ } \\
\text { hundreds-homes-moldgreen-dalton-tandem-7855557 } \\
\text { (Sutcliffe, 2014) }\end{array}$ \\
\hline 21 & $04 / 10 / 2014$ & 87 & $\begin{array}{l}\text { Burst water main. Major incident declared at Scun- } \\
\text { thorpe Hospital. No drinking water and toilet flushing } \\
\text { affected. Patients told not to attend } A+E \text { if possible. }\end{array}$ & $\begin{array}{l}\text { http://www.itv.com/news/calendar/update/2014-10-05/ } \\
\text { water-supplies-restored-to-hospital-in-lincolnshire } \\
\text { (ITV, 2014) }\end{array}$ \\
\hline 22 & $14 / 10 / 2014$ & 88 & $\begin{array}{l}\text { Burst main leads to void under road. Car becomes stuck } \\
\text { in hole. Both lanes closed. Many roads in Walton grid- } \\
\text { locked. Police called to scene. Council made aware. }\end{array}$ & $\begin{array}{l}\text { http://www.getsurrey.co.uk/news/surrey-news/ } \\
\text { car-trapped-sinkhole-opens-walton-7936966 } \\
\text { (Taylor, 2014) }\end{array}$ \\
\hline 23 & $04 / 11 / 2014$ & 11 & $\begin{array}{l}\text { Gas network flooded with water. } 400 \text { homes affected, } \\
\text { some for more than } 2 \text { days. Engineers required to carry } \\
\text { out safety checks, and reconnect gas. Customers off gas } \\
\text { for } 24+\text { hours are financially compensated. }\end{array}$ & $\begin{array}{l}\text { http://www.bbc.co.uk/news/ } \\
\text { uk-england-dorset-29929187 (BBC, 2014c) }\end{array}$ \\
\hline 24 & $18 / 11 / 2014$ & 87 & $\begin{array}{l}\text { Burst main - sandy torrent of water, flooded three } \\
\text { homes, turned road into "sodden beach". Water up to } \\
\text { knee height - water up to } 1 \mathrm{~m} \text { high in houses. No water. } \\
\text { No power. Road blocked for repair by police. Fire crews } \\
\text { required to pump water. } 15 \mathrm{~cm} \text { main. }\end{array}$ & $\begin{array}{l}\text { http://www.edp24.co.uk/news/environment/ } \\
\text { photo_gallery_burst_water_pipe_floods_road_in__ } \\
\text { dersingham_1_3851694 (Lynch, 2014) }\end{array}$ \\
\hline 25 & $28 / 11 / 2014$ & 93 & $\begin{array}{l}\text { Burst main fixed rapidly, but road remains closed to al- } \\
\text { low tarmac to set. Buses running } 60 \text { min late. }\end{array}$ & $\begin{array}{l}\text { http://www.bournemouthecho.co.uk/news/11633506. } \\
\text { Burst_water_main_repaired_but_traffic_misery_ } \\
\text { continues_for_motorists_in_Branksome/?ref=mr } \\
\text { (Astrup, 2014) }\end{array}$ \\
\hline 26 & $09 / 01 / 2015$ & 0 & $\begin{array}{l}5 \times 3.5 \times 1 \mathrm{~m} \text { deep sinkhole in garden from burst main. } \\
\text { Destroyed pavement and garden. Began as a small hole } \\
\text { in kerb. County Council called, but no one came so po- } \\
\text { lice called. Police put up barriers. The next day, huge } \\
\text { hole full of water. Anglian Water fixed the pipe when } \\
\text { called. }\end{array}$ & $\begin{array}{l}\text { http://www.northantstelegraph.co.uk/news/top- } \\
\text { stories/sinkhole-opens-up-at-bottom-of-cottingham- } \\
\text { garden-1-6509161 (Weaver, 2015) }\end{array}$ \\
\hline
\end{tabular}


Table A1. Continued.

\begin{tabular}{|c|c|c|c|c|}
\hline ID & Date $(\mathrm{d} / \mathrm{m} / \mathrm{yr})$ & Sand $\%$ & Summary of media report & URL \\
\hline 27 & $26 / 01 / 2015$ & 76 & $\begin{array}{l}\text { Burst main floods allotments. Complex fix as gas pipes } \\
\text { and power cables close to water main. } 15 \mathrm{~cm} \text { main. } \\
\text { Some properties off water. Bottled water provided. }\end{array}$ & $\begin{array}{l}\text { http://www.ilfordrecorder.co.uk/news/environment/ } \\
\text { burst_pipe_in_woodford_green_leaves_residents__ } \\
\text { without_water_and_an_allotment_flooded_1_3930119 } \\
\text { (Orrell, 2015) }\end{array}$ \\
\hline 28 & 27/01/2015 & 72 & $\begin{array}{l}\text { Road closed for } 3 \text { days after burst cause road to col- } \\
\text { lapse. Tree has fallen into hole. Ten houses off water for } \\
6 \mathrm{~h} \text {, but took much longer to fix the pipe, as the actual } \\
\text { leak was }>1 \mathrm{~km} \text { away from the damaged road. Diver- } \\
\text { sions in place. }\end{array}$ & $\begin{array}{l}\text { http://www.kentonline.co.uk/sevenoaks/news/ } \\
\text { road-collapse-leads-to-closure-30803/ } \\
\text { (McConnell, 2015) }\end{array}$ \\
\hline 29 & $29 / 01 / 2015$ & 40 & $\begin{array}{l}\text { Burst pipe. Flooding of five homes. Cut electricity sup- } \\
\text { ply and telephone lines. Bad PR for Yorkshire Water. }\end{array}$ & $\begin{array}{l}\text { http://www.thetelegraphandargus.co.uk/news/local/ } \\
\text { airelocal/11757812.Residents_face_flood_after_pipe_ } \\
\text { gives_out/ (Telegraph \& Argus, 2015) }\end{array}$ \\
\hline 29 & $29 / 01 / 2015$ & 40 & $\begin{array}{l}\text { Continuing from above: many gardens full of debris. } \\
\text { Main road flooded with stones and debris. Cut out BT } \\
\text { telecoms base - no phone/internet for several hours in } \\
\text { Shipley and Baildon. No credit card payments at ASDA } \\
\text { supermarket. Both fire and police involved. Sandbags } \\
\text { provided for people who need them. Rehoming for } \\
\text { those who required it. Emergency electrical work car- } \\
\text { ried out. Structural engineer needed to assess condition } \\
\text { of buildings. }\end{array}$ & 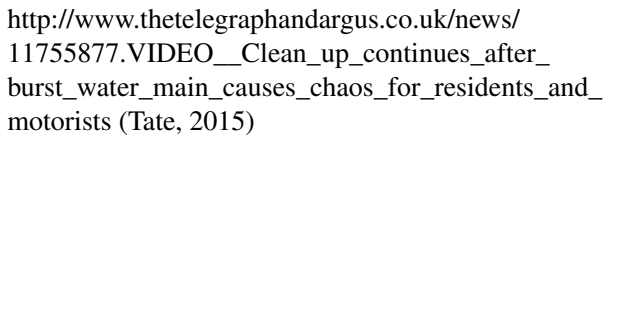 \\
\hline 30 & 03/02/2015 & 67 & $\begin{array}{l}\text { Burst main closes road. Water coming out of BT man- } \\
\text { hole. Water flowed onto carriageway and froze. Traffic } \\
\text { backed up } 3 \mathrm{~km} \text {. Gridlock on surrounding roads. One } \\
\text { primary school closed. }\end{array}$ & $\begin{array}{l}\text { http://www.sussexexpress.co.uk/news/county-news/ } \\
\text { a272-closed-at-buxted-1-6557919 } \\
\text { (Sussex Express, 2015) }\end{array}$ \\
\hline 31 & $04 / 02 / 2015$ & 89 & $\begin{array}{l}\text { Mains bursts. Floods roads. Blocks sewers. Debris } \\
\text { washing towards main road roundabout. Gas leak. Fire } \\
\text { crew and local council workers both involved to un- } \\
\text { block sewers. Police closed road. Hundreds of homes } \\
\text { off water. }\end{array}$ & $\begin{array}{l}\text { http://www.mynewtown.co.uk/viewerheadline/ } \\
\text { ArticleId/8437 (MyNewtown, 2015) }\end{array}$ \\
\hline 32 & 06/02/2015 & 86 & $\begin{array}{l}\text { Taxi stuck in } 1.5 \mathrm{~m} \text { wide pothole caused by burst water } \\
\text { main in Hampstead. Road affected for a number of days. }\end{array}$ & $\begin{array}{l}\text { http://www.hamhigh.co.uk/news/environment/taxi_ } \\
\text { stuck_in_pothole_caused_by_burst_water_main_in_ } \\
\text { hampstead_1_3946614 (Blake, 2015) }\end{array}$ \\
\hline 33 & 08/05/2015 & 40 & $\begin{array}{l}60 \mathrm{~cm} \text { hole in road. Caused by burst main or "drainage } \\
\text { pipe". Old mines also present in the area. }\end{array}$ & $\begin{array}{l}\text { http://www.stokesentinel.co.uk/ } \\
\text { 2ft-sinkhole-Fenton-road-caused-burst-water-pipe/ } \\
\text { story-21070606-detail/story.html (Barnes, 2015) }\end{array}$ \\
\hline 34 & $19 / 11 / 2015$ & 100 & $\begin{array}{l}1.8 \times 2.7 \mathrm{~m} \text { wide, } 1.8 \mathrm{~m} \text { deep void. Destroyed road. } \\
\text { Gardens flooded with sewage. Cascading failure dam- } \\
\text { ages proximal water mains (more bursts) and sewers } \\
\text { (damage). Sewage pumping stations no longer work- } \\
\text { ing as sand and gravel in the pumps. Exposes gas pipes. } \\
\text { Tankers pumping sewers "day and night". } 35 \text { properties } \\
\text { affected. }\end{array}$ & $\begin{array}{l}\text { http://www.kentonline.co.uk/romney-marsh/news/ } \\
\text { huge-sinkhole-opens-near-homes-27226/ } \\
\text { (Lennon, 2015) }\end{array}$ \\
\hline
\end{tabular}


Author contributions. TSF and SJ conceived the study. All authors were involved in data collection including the workshop, with TSF and SJ analysing the results. All authors contributed to the manuscript.

Competing interests. The authors declare that they have no conflict of interest.

Acknowledgements. This work was supported by NERC (NE/M008320/1) and EPSRC/ESRC (EP/I01344X/1; $\mathrm{EP} / \mathrm{K} 012347 / 1)$. The sponsors played no role in the study design or the collection, analysis or interpretation of the data, nor any role in the writing of the report or decision to publish these results. This research would not have produced the insights without the generous provision of data, time and expertise from the utility (water, gas, electrical distribution), highway (local and national), telecom and railway organisations, who provided invaluable input. The authors would also like to thank Caroline Keay and Ann Holden for their assistance in the creation of the new sand washout potential map and the cluster analysis tool and Daniel Farewell and Vern Farewell for statistical advice.

Edited by: Thomas Glade

Reviewed by: Timothy Acland and Kewan Mertens

\section{References}

Asphalt Industry Alliance: Annual Local Authority Road Maintenance Survey, Asphalt Industry Alliance, Bristol, 2016.

Astrup, J.: Burst water main repaired but traffic misery continues for motorists in Branksome, available at: http://www.bournemouthecho.co.uk/news/11633506.Burst_ water_main_repaired_but_traffic_misery_continues_for_ motorists_in_Branksome/?ref=mr (last access: 17 March 2017), 2014.

Barnes, L.: $2 \mathrm{ft}$ sinkhole in Fenton road caused by burst water pipe, available at: http://www.stokesentinel.co. uk/2ft-sinkhole-Fenton-road-caused-burst-water-pipe/ story-21070606-detail/story.html (last access: 20 March 2017), 2015.

BBC: Mains pipe flood closes main road, available at: http:// news.bbc.co.uk/1/hi/england/lincolnshire/8337851.stm (last access: 17 March 2017), 2009.

BBC: Great Western Way: Burst water main closes road, available at: http://www.bbc.co.uk/news/uk-england-wiltshire-22312127 (last access: 17 March 2017), 2013a.

BBC: Matlock flooded as water main and gas pipe crack, available at: http://www.bbc.co.uk/news/ uk-england-derbyshire-22050687 (last access: 17 March 2017), 2013b.

BBC: A6 in Leicestershire re-opens after Boxing Day burst water main, available at: http://www.bbc.co.uk/news/ uk-england-leicestershire-25619109 (last access: 17 March 2017), 2014a.
BBC: Bristol burst main leaves thousands without water, available at: http://www.bbc.co.uk/news/uk-england-bristol-29373980 (last access: 17 March 2017), 2014b.

BBC: Gas supplies restored to 400 Weymouth homes, available at: http://www.bbc.co.uk/news/uk-england-dorset-29929187 (last access: 17 March 2017), 2014c.

BBC: Gas supplies restored to Poole homes after water leak, available at: http://www.bbc.co.uk/news/ uk-england-dorset-29362291 (last access: 17 March 2017), 2014d.

BBC: Leicestershire road closes again after another water pipe bursts, available at: http://www.bbc.co.uk/news/ uk-england-leicestershire-25757918 (last access: 17 March 2017), 2014e.

Bevan, N.: Gas disruption in Nantyglo leaves hundreds of homes without heating and hot water, available at: http://www.walesonline.co.uk/news/local-news/ gas-disruption-nantyglo-leaves-hundreds-7660937 (last access: 20 March 2017), 2014.

Blake, H: Taxi stuck in pothole caused by burst water main in Hampstead, available at: http://www.hamhigh.co.uk/news/ environment/taxi_stuck_in_pothole_caused_by_burst_water_ main_in_hampstead_1_3946614 (last access: 17 March 2017), 2015.

Bowering, E. A., Peck, A. M., and Simonovic, S. P.: A flood risk assessment to municipal infrastructure due to changing climate part I: Methodology, Urban Water J., 11, 519-531, 2014.

Brink, A. B. A., Partridge, T. C., and Williams, A. A. B. (Eds.): Soil Survey for Engineering, Clarendon Press, Oxford, 1982.

Broome, P.: We're scared our houses are collapsing, available at: http://www.worcesternews.co.uk/news/10354380.We_ re_scared_our_houses_are_collapsing/ (last access: 20 March 2017) 2012 .

Butt, R.: Patchwork repairs to continue after third vehicle falls through road, available at: http://www.getsurrey.co.uk/news/surrey-news/ affinity-water-continue-patchwork-repairs-7000547 (last access: 21 March 2017), 2014.

Chalker, R. T. C., Pollard, S. J. T., Leinster, P., and Jude, S.: Appraising longitudinal trends in the strategic risks cited by risk managers in the international water utility sector, 2005-2015, Sci. Total Environ., 618, 1486-1496, 2018.

Committee on Climate Change: Adaptation Reporting Power: second round review, March 2017, Committee on Climate Change, London, 25 pp., 2017.

Cranfield University: NATMAPvector, the $1: 250,000$ scale Digital National Soil Map for England and Wales, available at: http:// www.landis.org.uk (last access: 13 September 2018), 2016.

Cranfield University: LandIS Land Information System (Soils data for England and Wales), available at: http://www.landis.org.uk, last access: 13 September 2018.

Dawson, R. J., Thompson, D., Johns, D., Gosling, S., Chapman, L., Darch, G., Watson, G., Powrie, W., Bell, S., Paulson, K., Hughes, P., and Wood, R.: UK Climate Change Risk Assessment Evidence Report: Chapter 4, Infrastructure. Report prepared for the Adaptation Sub-Committee of the Committee on Climate Change, London, 2016.

Defra: Climate Resilient Infrastructure: Preparing for a changing climate. Synthesis of the independent studies commissioned by 
the Government's Infrastructure and adaptation project, May 2011, Defra, London, 2011.

Defra: The National Adaptation Programme: Making the Country Resilient to a Changing Climate, July 2013, Defra, London, 84 pp., 2013.

Dudenhoffer, D., Permann, M., and Manic, M.: CIMS: A Framework for Infrastructure Interdependency Modeling and Analysis, Proceedings of the 2006 Winter Simulation Conference, https://doi.org/10.1109/WSC.2006.323119, December 2006.

getSurry: Burst water main leaves gaping hole in A320, available at: http://www.getsurrey.co.uk/news/local-news/ burst-water-main-leaves-gaping-4813168 (last access: 17 March 2017), 2011.

Guikema, S., Mclay, L., and Lambert, J. H.: Infrastructure Systems, Risk Analysis, and Resilience-Research Gaps and Opportunities, Risk Anal., 35, 560-561, 2015.

Hamilton, M.: Cromer water main fixed, available at: http://www.northnorfolknews.co.uk/news/cromer_water_ main_fixed_1_533520 (last access: 20 March 2017), 2009.

Harper, P.: Woking loses water supply due to burst pipe, available at: http://www.getsurrey.co.uk/news/surrey-news/ woking-loses-water-supply-due-6941235 (last access: 21 March 2017), 2014.

ITV: Water supplies restored to hospital in Lincolnshire, available at: http://www.itv.com/news/calendar/update/2014-10-05/ water-supplies-restored-to-hospital-in-lincolnshire (last access: 20 March 2017), 2014.

Jude, S. R., Drew, G. H., Pollard, S. J. T., Rocks, S. A., Jenkinson, K., and Lamb, R.: Science of the Total Environment. Delivering organisational adaptation through legislative mechanisms: Evidence from the Adaptation Reporting Power (Climate Change Act 2008), Sci. Total Environ., 574, 858-871, 2017.

Lennon, C.: Sinkhole causing havoc in Rolfe Road, New Romney - and it's getting bigger as Kent County Council tries to find a fix, available at: http://www.kentonline.co.uk/romney-marsh/ news/huge-sinkhole-opens-near-homes-27226/ (last access: 20 March 2017), 2015.

Lloyds Register Foundation: Foresight Review of resilience engineering: Designing for the expected and unexpected, October 2015, Report Series No. 2015.2, Lloyds Register Foundation, London, 2015.

Lynch, K.: Photo gallery: Burst water pipe floods road in Dersingham, available at: http://www.edp24.co.uk/news/environment/ photo_gallery_burst_water_pipe_floods_road_in_dersingham_ 1_3851694 (last access: 17 March 2017), 2014.

Majid, Z. A., Mohsin, R., Yaacob, Z., and Hassan, Z.: Failure analysis of natural gas pipes, Eng Fail Anal., 17, 818-837, 2010.

Marker, B. R.: Incorporation of information on geohazards into the planning process, Geohazards in Engineering Geology, Geological Society, London, Engineering Geology Special Publications, 15, edited by: Maund, J. G. and Eddleston, M., Geological Society, London, 385-389, 1998.

Martin, G.: River running down road' as burst water main hits gas supplies, available at: http://www.getsurrey.co.uk/ news/local-news/river-running-down-road-burst-6263464 (last access: 17 March 2017), 2013.

Martin, G.: Road closure after sinkhole appears posing risk to cars, available at: http://www.getsurrey.co.uk/news/surrey-news/ road-closure-after-sinkhole-appears- 7259207 (last access: 17 March 2017), 2014.

McConnell, E.: A227 Ightham Road closed between Bewley Lane and High Cross Road following collapse after burst main, available at: http://www.kentonline.co.uk/sevenoaks/news/ road-collapse-leads-to-closure-30803/ (last access: 20 March 2017), 2015.

Morris, G.: VIDEO: Ground "just collapsed" under car, driver says, available at: http://www.getsurrey.co.uk/news/local-news/ video-ground-just-collapsed-under-4809243 (last access: 17 March 2017), 2012.

Morris, J.: Car becomes lodged in burst water main hole, available at: http://www.getsurrey.co.uk/news/surrey-news/ car-becomes-lodged-burst-water-6983196 (last access: 17 March 2017), 2014.

MyNewtown: Gas alert after mains water pipe burst, available at: http://www.mynewtown.co.uk/viewerheadline/ArticleId/ 8437 (last access: 20 March 2017), 2015.

Ofwat: Resilience in the Round, available at: https://www.ofwat. gov.uk/publication/resilience-in-the-round/ (last access: 1 October 2018), ISBN 978-1-911588-11-5, 2017.

Orrell, H.: Burst pipe in Woodford Green leaves residents without water and an allotment flooded, available at: http://www.ilfordrecorder.co.uk/news/environment/burst_ pipe_in_woodford_green_leaves_residents_without_water_ and_an_allotment_flooded_1_3930119 (last access: 20 March 2017), 2015.

OS (Ordnance Survey): Ordnance Survey Open Roads Dataset, available at: https://www.ordnancesurvey.co.uk/ opendatadownload/products.html\#OPROAD (last access: 13 September 2018), 2016.

Pritchard, O. G., Hallett, S. H., and Farewell, T.S.: Soil impacts on UK infrastructure: current and future climate, P. I. Civil Eng.Eng. Su., 167, 170-184, 2014a.

Pritchard, O. G., Hallett, S. H., and Farewell, T. S.: Cracking up in Lincolnshire, Geoscientist, March, 2014, 24, 14-19, 2014b.

Pritchard, O. G., Hallett, S. H., and Farewell, T. S.: Probabilistic soil moisture projections to assess Great Britain's future clay-related subsidence hazard, Clim. Change, 133, 635-650, 2015 a.

Pritchard, O. G., Hallett, S. H., and Farewell, T. S.: Soil geohazard mapping for improved asset management of UK local roads, Nat. Hazards Earth Syst. Sci., 15, 2079-2090, https://doi.org/10.5194/nhess-15-2079-2015, 2015b.

Rinaldi, S. M., Peerenboom, J. P., and Kelly, T. K.: Identifying, understanding, and analyzing critical infrastructure interdependencies, IEEE Contr. Syst. Mag., 21, 11-25, 2001.

Rogers, C. D. F., Bouch, C. J., Williams, S., Barber, A. R. G., Baker, C. J., Bryson, J. R., Chapman, D. N., Chapman, L., Coaffee, J., Jefferson, I., and Quinn, A. D.: Resistance and Resilience - paradigms for critical local infrastructure, P. I. Civil Eng.Munic., 165, 73-84, 2012.

Sadana, J.: The Coding Manual for Qualitiative Researchers, 2nd edition, SAGE, Los Angeles, 303 pp., 2013.

Street, R. B., Hayman, V., and Wilkins, T. M.: Understanding the value of the Adaptation Reporting Power process to the reporting organisations involved, UKCIP, University of Oxford, 30 pp.., 2017.

Sussex Express: A272 closed at Buxted, available at: http://www.sussexexpress.co.uk/news/county-news/ 
a272-closed-at-buxted-1-6557919 (last access: 20 March 2017), 2015.

Sutcliffe, T.: Hundreds of homes in Moldgreen, Dalton and Tandem without gas after water main burst, available at: http://www.examiner.co.uk/news/west-yorkshire-news/ hundreds-homes-moldgreen-dalton-tandem-7855557 (last access: 20 March 2017), 2014.

Talbot, C.: Gardens and drives flooded after A320 water main burst, available at: http://www.getsurrey.co.uk/news/surrey-news/ gardens-drives-flooded-after-a320-6860355 (last access: 21 March 2017), 2014.

Tate, C. : VIDEO: Clean-up continues after burst water main causes chaos for residents and motorists, available at: http://www.thetelegraphandargus.co.uk/news/11755877.

VIDEO_Clean_up_continues_after_burst_water_main_ causes_chaos_for_residents_and_motorists (last access: 20 March 2017), 2015.

Taylor, A., de Bruin, W. B., and Dessai, S.: Climate change beliefs and perceptions of weather-related changes in the United Kingdom, Risk Anal., 34, 1995-2004, 2014.

Taylor, B.: Car trapped as sinkhole opens in Walton, available at: http://www.getsurrey.co.uk/news/surrey-news/ car-trapped-sinkhole-opens-walton-7936966 (last access: 17 March 2017), 2014.

Telegraph \& Argus: Residents face flood after pipe gives out, available at: http://www.thetelegraphandargus.co.uk/news/local/ airelocal/11757812.Residents_face_flood_after_pipe_gives_out/ (last access: 20 March 2017), 2015.

UK Roads Board.: SCANNER surveys for local roads, User guide and specification Volume 3, Advice to local authorities: Using SCANNER survey results, UK Roads Board, available at: http://pcis.org.uk/iimni/UserFiles/Applications/Documents/ Downloads/SCANNERandTTS/SCANNERSpecification/

SCANNER_Spec_2011_Volume_3.pdf (last access: 15 July 2015), 2011.
Weaver, S.: Sinkhole opens up at bottom of Cottingham garden, available at: http:// www.northantstelegraph.co.uk/news/top-stories/ sinkhole-opens-up-at-bottom-of-cottingham-garden-1-6509161 (last access: 20 March 2017), 2015.

Worcester News: Worcester junction is reopened after leak in pipes, available at: http://www.worcesternews.co.uk/news/10120224. Road_is_reopened_after_leak_in_pipes/ (last access: 20 March 2017), 2012.

Young, K. and Hall, J. W.: Introducing system interdependency into infrastructure appraisal: from projects to portfolios to pathways, Infrastructure Complexity, 2, https://doi.org/10.1186/s40551015-0005-8, 2015.

Wallis, J.: The UKPMS User Manual Volume 2: Visual Data Collection for UKPMS Chapter 7: CVI, available at: http://pcis.org.uk/iimni/UserFiles/Applications/ Documents/Downloads/UKPMSManualsandGuides/Manual/ UKPMSManual_02_07v09.pdf (last access: 15 July 2015), 2009.

Zimmerman, R.: Decision-making and the vulnerability of interdependent critical infrastructure IEEE International Conference on Systems, Man and Cybernetics, SMC 2004, The Hague, Netherlands, 10 October 2004 through 13 October 2004; Category number 04CH37583, Code 64440, 5, 4059-4063, 2004. 